\title{
PELATIHAN KELOMPOK WANITA TANI DALAM PEMANFAATAN EM4 TERHADAP PEMBUATAN PUPUK KOMPOS
}

\author{
Aldi Rizki Putra*1, Kiki Afandi ${ }^{2}$, Dewi Anjani ${ }^{3}$, Kenny Candra Pradana ${ }^{4}$ \\ ${ }^{1,2,3}$ Universitas Islam Negeri Raden Intan, Lampung \\ ${ }^{4}$ Universitas Sang Bumi Ruwa Jurai, Lampung \\ e-mail: *11 aldirizkiputra11@gmail.com, ${ }^{2}$ kikiafandi37@gmail.com, ${ }^{3}$ anjanidewi571@gmail.com, \\ kennycandrapradana@gmail.com
}

\begin{abstract}
Abstrak
Banyaknya jumlah peternak menjadikan desa Marga Kaya sebagai sektor usaha milik desa dan juga luasnya lahan persawahan membuat warga tidak kekurangan bahan pangan, namun dari semua itu timbul limbah di lingkungan sekitar yang berasal dari peternakan dan pabrik penggiling padi. Oleh sebab itu, tujuan pelatihan ini adalah untuk melatih dan memberdayakan Kelompok Wanita Tani (KWT) di desa Marga Kaya ini dalam membuat pupuk kompos dengan menggunakan kotoran ternak, dan sekam padi untuk mengurangi limbah ternak dan limbah pabrik padi serta memanfaatkan EM4 untuk meningkatkan kesuburan tanah nantinya. Metode yang digunakan ialah pelatihan dengan peserta pelatihan sebanyak 20 anggota KWT. Dengan adanya pelatihan ini, mendapatkan hasil yakni masyarakat terutama kelompok wanita tani menjadi paham tentang cara mengolah limbah kotoran ternak dan limbah sekam padi yang dicampur dengan EM4 untuk dijadikan pupuk kompos serta kegiatan ini dapat mengurangi limbah yang ada di desa tersebut menjadi hal yang lebih bermanfaat.
\end{abstract}

Kata kunci: Pelatihan, EM4, Pupuk, Kompos, Kelompok Wanita Tani

\begin{abstract}
The large number of breeders makes Marga Kaya village a village-owned business sector and also the vast rice fields make residents not short of food, but from all of this there is waste in the surrounding environment that comes from farms and rice mills. Therefore, the aim of this training is to train and empower the Women Farmers Group (KWT) in this Marga Kaya village to make compost using livestock manure, and rice husks to reduce livestock waste and rice factory waste and utilize EM4 to improve soil fertility later. The method used is training with 20 KWT participants. With this training, getting results, namely the community, especially women farmer groups, will understand how to process livestock manure and rice husk waste mixed with EM4 to become compost and this activity can reduce the waste in the village to be more useful.
\end{abstract}

Keywords: Training, EM4, fertilizer, compost, women farmer groups

\section{PENDAHULUAN}

Indonesia memiliki beberapa sektor yang penting, dari sektor pertanian, pendidikan, pembangunan, dan lain lain. Salah satu sektor yang paling penting ialah sektor pertanian. Sektor pertanian di Indonesia dijadikan sebagai fondasi dalam pembangunan nya. Pada sektor pertanian terdapat salah satu subsektor yang memiliki peran penting dalam menunjang pembangunan dan perekonomian nasional, subsektor tersebut ialah subsektor hortikultura. Pernyataan tersebut didukung bahwa wilayah Indonesia sebagai daerah yang sangat berpotensial untuk mengembangkan komoditas hortikultura yang dimana karakteristik lahan dan agroklimat serta sebaran wilayah yang luas[1].

Lahan pertanian di Indonesia mempunyai 
bahan organik tanah yang cukup rendah sekitar $2 \%$. Oleh sebab itu, penggunaan bahan tambahan atau bahan organik perlu diberikan. Bahan organik yang berasal dari limbah tanaman pangan, perkebunan, ataupun limbah kotoran ternak. Bahan organik atau bisa disebut pupuk organik berasal dari proses fermentasi secara alami atau melalui bantuan aktivator. Tanaman sangat membutuhkan kandungan unsur mikro dan makro, oleh sebab itu, pupuk organik sangat dipercaya sebagai pelengkap dalam proses pertumbuhan tanaman[2].

Desa Marga Kaya merupakan salah satu desa yang terletak di Kecamatan Jati Agung, Kabupaten Lampung Selatan, Provinsi Lampung. Desa yang terkenal dengan ikon tugu sapi ini menggambarkan bahwa hampir seluruh warganya memiliki peternakan sapi. Desa ini memiliki perhatian khusus pada bidang pertenakan dan pertanian, karena desa ini memiliki kondisi tanah yang ternilai cukup subur. Desa Marga Kaya pun memiliki sebuah kelompok wanita tani, dimana kelompok ini biasa disebut dengan sebutan KWT. Setiap anggota Kelompok Wanita Tani memiliki lahan kosong didepan halaman rumahnya yang akhirnya ditanami sayuran dan biasa menggunakan polibeg sebagai media tanamnya. Dan Kelompok Wanita Tani ini memiliki satu lahan khusus dengan luas lahan 9 x 4 meter yang terletak didekat rumah dari ketua Kelompok Wanita Tani, dimana $1 / 4$ dari lahan ini biasanya dipakai untuk penyemaian bibit sayuran dan $3 / 4$ lahan lagi digunakan untuk penanaman sayuran.
Di dalam penyemaian bibit sayuran, biasanya para kelompok wanita tani hanya menggunankan tanah dan pupuk kandang saja. Perlu kita ketahui, sebenarnya pupuk itu dibagi menjadi dua, yaitu pupuk organik dan pupuk anorganik. Pupuk anorganik adalah pupuk hasil proses rekayasa secara kimia, fisik, dan atau biologis yang merupakan hasil industri atau pabrik pembuatan pupuk[3]. Sedangkan, pupuk organik merupakan pupuk yang tersusun dari materi makhluk hidup yang terbentuk oleh proses pembusukan (dekomposisi) dari bakteri pengurai, seperti pelapukan dari sisa-sisa tanaman, hewan dan manusia. Pupuk organik pun dapat berupa padat dan cair untuk memperbaiki sifat fisik, kimia, dan biologi dari tanah. Karena pupuk organik ini sangat mudah untuk didiapatkan, maka banyak sekali sumber dayanya. Pupuk organik juga merupakan bahan pembenah tanah yang paling baik dibandingkan bahan pembenah lainya[4].

Ternyata sebelum adanya pelatihan tentang pembuatan pupuk kompos yang berbahan kotoran sapi, sekam bakar, sekam mentah dan pemanfaatan EM4. Kelompok wanita tani hanya menggunakan kotoran ternak sapi saja, atau hanya menggunakan campuran antara kotoran ternak sapi dengan sekam mentah tanpa ada tambahan tambahan lainnya dalam penanaman sayuran.

Pemanfaatan kotoran sapi digunakan untuk pembuatan biogas. Biogas merupakan renewable energi yang dapat dijadikan bahan bakar alternatif untuk menggantikan bahan bakar 
yang berasal dari fosil. Biogas yang berasal dari campuran kotoran sapi mengasilkan gas dengan nyala api biru sehingga dapat digunakan untuk memasak[5]. Namun dalam penelitian ini, peneliti melakukan pelatihan menggunakan kotoran sapi sebagai pembuatan pupuk kompos.

Pemilihan kotoran sapi guna menjadi pupuk organik menurut Djuamani dkk, pada dasarnya kotoran ternak (sapi, kambing, ayam, dll) merupakan bahan yang sangat baik untuk pembuatan pupuk kompos, karena kotoran sapi merupakan limbah organik yang didalamnya mengandung banyak protein dan nutrisi yang baik bagi pertumbuhan tanaman. Namun pupuk organik yang hanya berasal dari kotoran sapi saja hanya mempunyai kandungan unsur hara yang rendah yaitu $1,26 \% \quad \mathrm{~N}, \quad 1,03 \% \quad \mathrm{P}_{2} \mathrm{O}_{5}, 1,07 \%$ $\mathrm{K}_{2} \mathrm{O}[6]$. Rendahnya unsur hara yang dimiliki oleh kotoran sapi, menyebabkan perlunya penambahan limbah organic lainnya seperti sekam bakar, sekam mentah, dan EM4 yang menjadi aktifator untuk menambah unsur hara dan memperbaiki sifat fisik tanah dan kimia tanah.

Penambahan bahan lain guna menambah unsur hara pada kotoran sapi maka pada pelatihan ini terdapat penambahan bahan dengan menggunakan sekam bakar, sekam mentah dan Em4. Sekam padi menjadi salah satu limbah yang memiliki banyak manfaatnya. Manfaat tersebut seperti Sebagai pakan ternak, bahan pembuat telur asin, penyerap limbah di lingkungan seperti merkuri dan timbal di perairan, dan sebagai sumber energi[7]. Sekam padi yang digunakan pada penambahan unsur hara bagi tanaman dibagi menjadi dua yaitu sekam padi bakar atau disebut dengan arang sekam dan sekam padi yang belum dibakar.

Sekam bakar merupakan salah satu jenis pupuk organik yang dikatakan mampu untuk memperbaiki sifat tanah dan hasil tanaman. Sekam bakar yang berasal dari pembakaran kulit padi kering dan disiram sebelum menjadi abu. Pembuatannya dapat dilakukan dengan menyangrai atau membakar. Sekam bakar memiliki karakteristik yang istimewa. Sekam bakar memiliki komposisi kimiawi seperti $\mathrm{SiO}_{2}$ dengan kadar $52 \%$ dan $\mathrm{C}$ sebanyak $31 \%$, dan kandungan lainnya terdiri dari $\mathrm{Fe} 2 \mathrm{O} 3, \mathrm{~K} 2 \mathrm{O}$, $\mathrm{MgO}, \mathrm{CaO}, \mathrm{MnO}$, dan $\mathrm{Cu}$ dengan jumlah kadar yang kecil. Sekam bakar memiliki peran penting dalam perbaikan sifat fisik, sifat kimia dan melindungi tanah[8].

Sekam padi merupakan salah satu limbah yang banyak sekali manfaatnya. Limbah pertanian ini bukan hanya berfungsi sebagai pakan ternak atau abu gosok saja, melainkan sebagai pupuk organik juga. Bahkan, abu dari sekam padi juga dapat digunakan untuk pembuatan telur asin. Berdasarkan penelitian dari Rahmatan dan Safrianti tentang pengaruh konsentrasi garam terhadap kadar protein telur yang diasinkan oleh abu sekam padi. Menurut Feng, Lin et al., sekam padi berfungsi sebagai penyerap limbah-limbah lingkungan yang pada akhirinya mereka memanfaatkan sekam padi ini 
untuk menyerap timbal dan merkuri yang berada di perairan. Bahkan sekam padi juga dapat digunakan sebagai sumber energi yang dapat diperbarui. Penelitian yang dilakukan Hermawan (2003) berpendapat bahwa sekam padi mampu menyuburkan tanah yang memiliki sifat asam dan mengandung unsur Al yang tinggi dan menimbulkan racun sehingga tidak baik untuk tanaman. Tanah tersebut bisa disebut dengan tanah ultisol yang dipergunakan untuk menanam kedelai. Oleh sebab itu penambahan sekam padi mampu meningkatkan unsur $\mathrm{P}, \mathrm{K}$, dan $\mathrm{C}$ pada tanah. Pemanfaatan lain sekam padi menjadi pupuk organik melalui proses pengomposan yang dibantu dengan cacing atau disebut dengan vermicomposing [7].

Terdapat beberapa jenis EM4, seperti halnya EM4 untuk peternakan dan EM4 untuk pertanian. EM4 (Effective Mircoorganisme) adalah suatu cairan yang memiliki warna kecoklatan dan memiliki aroma manis asam (segar) yang didalamnya berisi campuran beberapa mikroorganisme hidup yang bermanfaat bagi proses penyerapan / persediaan unsur hara dalam tanah. Mikroorganisme atau kuman yang sifatnya baik terdiri dari bakteri fotosintesik, bakteri asam laknat, ragi, aktinomydates, dan jamur peragian[9]. Penggunaan EM4 merupakan bahan awal untuk membuat pertanian akrab lingkungan dengan memanfaatkan mikroorganisme pembusuk yang bermanfaat dalam kesuburan tanah, dengan cara pembuatan pupuk kandang ditanmbahkan EM4 atau sejenisnya, sesuai dengan dosis atau penggunaan yang pas berdasarkan petunjuk penggunaan. Berlandaskan hal tersebut, maka organisme di dalam tanah akan tumbuh subur kembali[10].

Penelitian yang dilakukan oleh [11], tentang pembuatan pupuk organik cair dari limbah buah dengan penambahan bioaktivator em4 menghasilkan konsentrasi C-organik: 3,97 $34 \%$, N: 1,37 - 3,21\%, P: 2,22 - 3,81\% dan K: 2,48 - 4,24\%. Produk pupuk organik cair dengan bahan baku limbah buah pisang dan penambahan EM4 sebanyak $50 \mathrm{~mL}$ merupakan penyampuran optimal dibandingkan dengan yang lainnya, dimana konsentrasi $\mathrm{N}$, $\mathrm{P}$, dan $\mathrm{K}$ pupuk organik cair dengan buah pisang dan EM4 $50 \mathrm{~mL}$ memenuhi baku mutu berdasarkan Peraturan Menteri Pertanian Nomor 261 tahun 2019, tetapi konsentrasi C-organik belum memenuhi baku mutu.

[12] melakukan penelitian yaitu tentang pembuatan pupuk organik cair dari sampah organik rumah tangga dengan bioaktivator EM4. Berdasarkan hasil penelitian mendapatkan hasil sebagai berikut : proses pembuatan pupuk organik cair menggunakan penambahan volume EM4 efektif dalam meningkatan kandungan $\mathrm{N}, \mathrm{P}$, dan C ; penambahan volume EM4 meningkatkan kandungan $\mathrm{N}, \mathrm{P}$, dan $\mathrm{C}$ secara fluaktif : dan semakin lama proses pengomposan dan semakin besar penambahan volume EM4, cenderung menurunkan kadar K.

Penelitian yang dilakukan oleh [13], menghasilkan kesimpulan berupa pengomposan 
menggunakan bioaktivator MOL limbah tomat dan EM4 berjalan dengan normal berdasarkan gambaran fluktuasi suhu, $\mathrm{pH}$, dan kelembaban harian, serta terjadinya penyusutan volume akibat degradasi bahan organik oleh microorganism pengurai. Dalam waktu 3 minggu, parameter fisik (warna, bau, tekstur) dan parameter kimia khususnya $\mathrm{C} / \mathrm{N}$ rasio kompos telah mengalami penguraian serta memenuhi standar kualitas menurut kriteria SNI 19-7030-2004.

Dari penelitian sebelumnya maka pengabdi melakukan sebuah pembaharuan pelatihan kelompok wanita tani dengan pembuatan pupuk kompos padat yang dicampurkan oleh EM4 di Desa Marga Kaya. Perlu diketahui, pelatihan ini merupakan suatu proses pembelajaran yang lebih menekankan praktek dari pada teori yang dilakukan seseorang atau kelompok dengan menggunakan pendekatan berbagai pembelajaran[14]. Maka, tujuan melaksanakan kegiatan ini adalah untuk mengedukasi masyarakat agar mengetahui lebih banyak tentang cara pembuatan pupuk kompos dengan menggunakan bahan - bahan tersebut agar kelompok wanita tani mampu memanfaatkan kotoran sapi dan sekam padi yang dicampur EM4 untuk mengurangi limbah lingkungan.

\section{METODE}

Kegiatan pelatihan ini dilakukan pada tanggal 23 juli 2020 di rumah ketua Kelompok
Wanita Tani desa Marga Kaya, Kecamatan Jati Agung, Kabupaten Lampung Selatan. Peserta kegiatan ini merupakan anggota dari kelompok wanita tani. metode yang digunakan adalah metode pelatihan masyarakat. Tahap pelatihan merupakan kegiatan aplikatif membuat pupuk organik dari limbah pertanian dan/atau ternak. Pelaksanaannya dilakukan dengan alat dan bahan yang tersedia di desa Marga Kaya agar mudah dalam pembuatannya[15]. Mula - mula, Kelompok Wanita Tani diberikan penyuluhan secara singkat tentang pembuatan pupuk kompos dengan menggunakan kotoran sapi yang dicampurkan oleh sekam bakar, sekam mentah, serta memanfaatkan EM4 sebagai campurannya. Setelah itu, dilanjutkan dengan praktek langsung pembuatan pupuk kompos menggunakan bahanbahan yang sudah disebutkan di atas. Berikut merupakan uraian dari langkah - langkah pelatihan kepada kelompok wanita tani, yaitu sebagai berikut :

- Siapkan terlebih dahulu bahan yang akan digunakan dengan perbandingan $3: 2: 1$ : 1. Makna nya ialah 3 ember kotoran sapi, 2 ember sekam mentah, 1 ember sekam bakar, 1 tutup botol EM4 dengan campuran air 1 liter.

- Campurkan kotoran sapi, sekam mentah, dan sekam bakar. Aduk hingga semuanya tercampur

- Tuangkan 1 tutup botol atau $10 \mathrm{ml} \mathrm{Em4}$ kedalam 1 liter air 
- Kemudian tuangkan larutan Em4 tadi ke dalam campuran kotoran sapi, sekam mentah, dan sekam bakar dan aduk hingga semua tercampur

- Masukan bahan tadi kedalam plastik dan di ikat sampai kencang lalu diamkan dan simpan ditempat yang kering .

- Jika menggunakan kotoran sapi yang masih sedikit basah, maka memerlukan waktu \pm 2 bulan untuk pupuk siap digunakan.

Dan, jika menggunakan kotoran sapi yang sudah kering, maka memerlukan waktu \pm 5 hari agar pupuk kompos siap untuk digunakan.

\section{HASIL DAN PEMBAHASAN}

Kegiatan pelatihan pembuatan pupuk kompos yang dilakukan di desa Marga Kaya, Kecamatan Jatiagung, Kabupaten Lampung Selatan bersama dengan kelompok wanita tani ini yang menggunakan bahan dasar berupa kotoran sapi yang ditambahkan dengan sekam mentah, sekam bakar, serta EM4 berjalan dengan baik dan kelompok wanita tani memiliki semangat serta antusias dalam penyuluhan ini. Karena, kelompok wanita tani mendapatkan keterbaruan dari pemanfaatan limbah kotoran sapi dan sekam padi yang selama ini hanya digunakan sebatasnnya saja.

Kegiatan yang pertama dilakukan adalah melakukn penyuluhan materi yang tujuannya untuk mengetahui apa saja manfaat dari masing - masing bahan yang akan di gunakan untuk pembuatan pupuk kompos yang memanfaatkan EM4 sebagai campuran. Yaitu dijelaskan apa saja manfaat dari kotoran sapi, sekam mentah, sekam bakar, dan EM4 sebelum akhirnya dilakukan pelatihan pembuatan pupuk kompos. Lalu, dijabarkan secara singkat juga tentang cara pembuatan dari pupuk kompos.

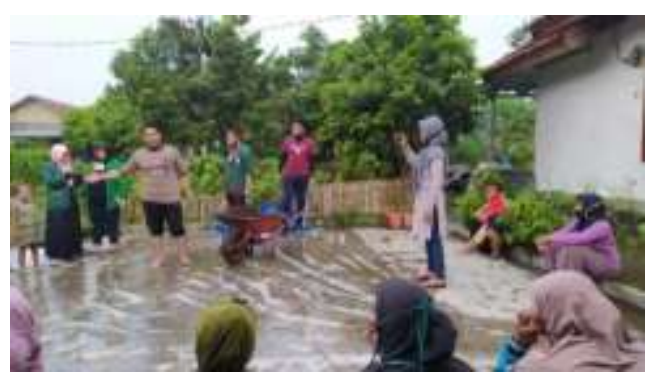

Gambar 1. Penyuluhan materi

Kegiatan selanjutnya yaitu memulai praktek pembuatan pupuk kompos yang diawali dengan melakukan pencampuran bahan antara lain 3 ember kotoran sapi, 2 ember sekam mentah, dan 1 ember sekam bakar. Semua bahan itu dicampur hingga merata.

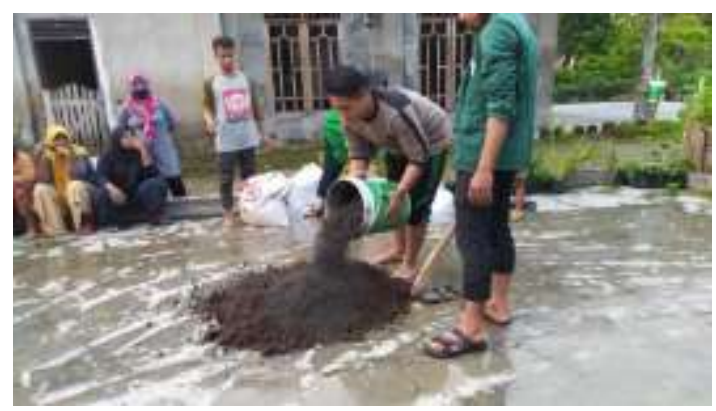

Gambar 2. Pencampuran bahan

Setelah bahan merata dilanjutkan dengan memproses EM4 dengan mencmpurnya dengan air. 


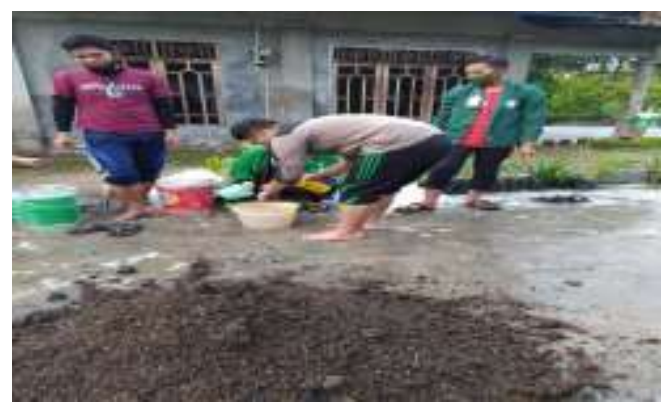

Gambar 3. Pencampuran EM4

Pencampuran EM4 dengan air 1 liter dengan maksud melarutkan EM4. Pencampuran ini bertujuan untuk mengaktifkan mikroorganisme yang terkandung dalam EM4 karena mikroorganisme tersebut sedang dalam kondisi tidur. Setelah dilarutkan, EM4 yang sudah tercampur dngan air digabungkan dengan adukan kotoran sapid an sekam padi yang sudah diaduk sebelumnya. Setelah semua bahan diaduk, hasil adukan yang sudah tercampur tadi dimasukkan kedalam plastik yang sudah disiapkan. kemudian ditutup rapat sehingga tidak ada lagi oksigen yang masuk dan ini dinamakan anaerob.

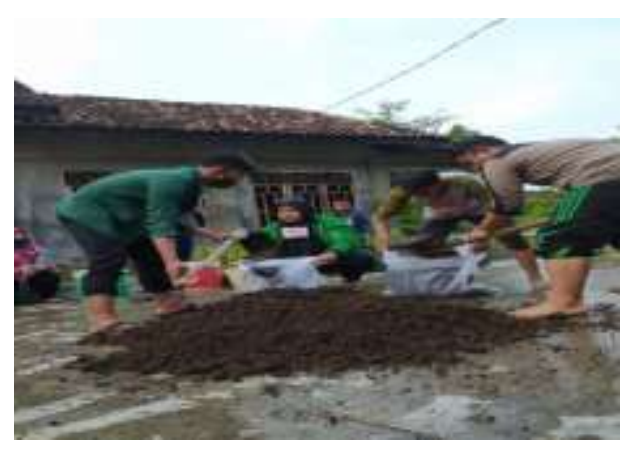

Gambar 4. Proses memasukkan semua bahan kedalam plastik.

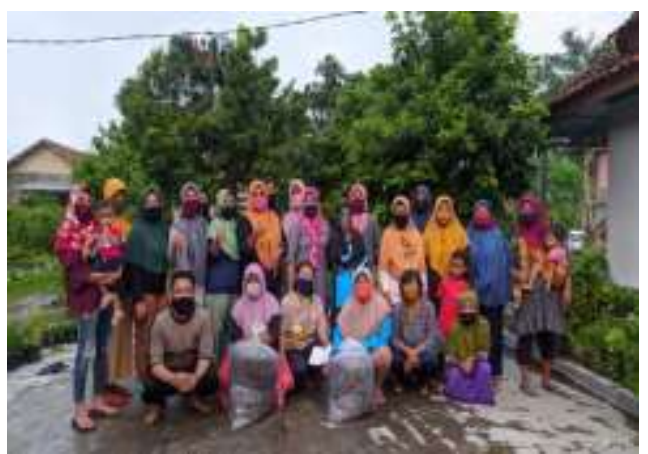

Gambar 5. Hasil dari pembuatan pupuk kompos bersama KWT

Setelah semua bahan tadi dimasukkan kedalam plastic, tahap akhir dari pembuatan pupuk kompos ini adalah menyimpan plastik yang berisi adukan tadi ke tempat yang kering lalu disimpan dalam kurun waktu \pm 5 hari setelah 5 hari, pupuk tersebut dapat dibuka dan sudah dapat digunakan oleh kelompok wanita tani di Desa Marga kaya.

Pada akhirnya. setelah adanya pelatihan pembuatan pupuk kompos ini, kelompok wanita tani bahkan masyarakat tahu apa saja kandungan yang terdapat pada sekam pagi dan kotoran sapi, mereka tau tentang manfaat penggunaan EM4 sebagai campuran dari pembuatan pupuk kompos serta cara pembuatannya.

\section{SIMPULAN}

Dari hasil tersebut juga dapat disimpulkan bahwa pelaksanaan pelatihan ini mendapat respon yang positif dan antusias yang tinggi dari kelompok wanita tani karena bertambahnya pengetahuan yang dimiliki oleh kelompok wanita tani akan kandungan dari kotoran sapi, sekam padi, sekam bakar dan EM4. Mereka juga tahu 
mengenai pembuatan kompos dengan menggunakam kotoran sapi dan sekam padi yang dicampur dengan EM4 untuk dijadikan sebagai pupuk kompos yang baik untuk tanaman, serta secara tidak langsung dapat mengurangi limbah lingkungan.

\section{SARAN}

Berdasarkan kegiatan yang sudah dilakukan, pengabdi berharap semoga terdapat program-program pengabdian masyarakat lainnya yang mampu memanfaatkan limbah lingkungan guna menjadi alternatif atau solusi bagi masyarakat.

\section{DAFTAR PUSTAKA}

[1] F. Deviani, D. Rochdiani, and B. R. Saefudin, "ANALISIS FAKTORFAKTOR YANG MEMPENGARUHI PRODUKSI USAHATANI BUNCIS DI GABUNGAN KELOMPOK TANI LEMBANG AGRI KABUPATEN BANDUNG BARAT (Analysis,” Agrisocionomics J. Sos. Ekon. dan Kebijak. Pertan., vol. 3, no. 2, pp. 165-173, 2019.

[2] A. Jamil and S. Anggraini, "Potensi Limbah Pertanian sebagai Pupuk Organik Lokal di Lahan Kering Dataran Rendah Iklim Basah," Iptek Tanam. Pangan, vol. 6, no. 2, pp. 193-202, 2015.

[3] F. G. Dewanto, J. J. M. R. Londok, R. A. V.
Tuturoong, and W. B. Kaunang, "Pengaruh Pemupukan Anorganik Dan Organik Terhadap Produksi Tanaman Jagung Sebagai Sumber Pakan.," Zootec, vol. 32, no. 5, pp. 1-8, 2017, doi: 10.35792/zot.32.5.2013.982.

[4] H. Wijayanto, D. Riyanto, B. Triyono, and U. Muhammadiyah, "DESIMINASI PRODUK TEKNOLOGI MESIN PENGOLAH PUPUK ORGANIK DESA JATI MALANG KECAMATAN ARJOSARI KABUPATEN PACITAN," vol. 2, no. 1, pp. 1-5, 2018.

[5] V. N. April, "Penerapan Ilmu Manajemen dalam Pengembangan Agroindustri Biogas dari Limbah Kotoran Sapi yang Berdampak pada Kesejahtraan Masyarakat Desa Sindanglaya Kec. Tanjungsiang, Kab. Subang Application,” vol. 1, no. 2, pp. 7586, 2020.

[6] A. dan I. J. Ade Rakhmadi, "TEKNOLOGI PEMBUATAN KOMPOS KOTORAN SAPI SIMENTAL DENGAN PENGGUNAAN TITHONIA (Thitonia diversifolia) DAN MOL REBUNG PADA KELOMPOK TANI TERNAK," $J$. Hilirisasi IPTEKS, vol. 1, no. 3, pp. 54-59, 2018, doi: 10.25077/hilirisasi.1.3.5055.2018 .

[7] Husnawati Yahya, "KAJIAN BEBERAPA MANFAAT SEKAM PADI DI BIDANG TEKNOLOGI LINGKUNGAN: SEBAGAI UPAYA PEMANFAATAN 
LIMBAH PERTANIAN BAGI MASYARAKAT ACEH DI MASA AKAN

DATANG Husnawati," vol. 4, no. 1, pp. 266-270, 2017.

[8] M. Same, R. Gusta, and A. R. Gusta, "Pengaruh Sekam Bakar dan Pupuk NPK Pada Pertumbuhan Bibit Lada The Effect of Roasted Husks and NPK Fertilizer on Growth of Pepper," J. Penelit. Pertan. Terap., vol. 19, no. 3, pp. 217-224.

[9] D. Irawan and E. Suwanto, "Pengaruh Em4 (Effective Microorganisme) Terhadap Produksi Biogas Menggunakan Bahan Baku Kotoran Sapi," Turbo J. Progr. Stud. Tek. Mesin, vol. 5, no. 1, pp. 44-49, 2017, doi: 10.24127/trb.v5i1.118.

[10] N. Ekawandani and T. Kimia, "EFEKTIFITAS KOMPOS DAUN MENGGUNAKAN EM4 DAN KOTORAN SAPI," vol. 12, no. 2, pp. 145149, 2018.

[11] B. W. R. I. H. Putra and R. Ratnawati, "Pembuatan Pupuk Organik Cair dari Limbah Buah dengan Penambahan Bioaktivator EM4," J. Sains dan Teknol. Lingkung., vol. 11, no. 1, pp. 44-56, 2019.

[12] T. Nur, A. R. Noor, and M. Elma, "Pembuatan Pupuk Organik Cair Dari Sampah Organik Rumah Tangga Dengan Penambahan Bioaktivator EM4 (Effective Microorganisms)," Konversi, vol. 5, no. 2, pp. 2016, 44-51, doi: 10.20527/k.v5i2.4766.
[13] A. Naomi, "Penggunaan EM4 dan Mol Limbah Tomat Sebagai Bioaktivator Pada Pembuatan Kompos,” vol. 5, no. 1, pp. 1824, 2016.

[14] Budi Santoso, Skema dan Mekanisme Pelatihan: Panduan Penyelenggaraan Pelatihan. 2012.

[15] S. Suherman, N. Nurhapsa, and I. Irmayani, "Pemberdayaan Masyarakat Tani di Desa Batu Mila Melalui Pelatihan Pembuatan Pupuk Organik dari Limbah Pertanian," Pros. Semnas 2018 Sinergitas Multidisiplin Ilmu Pengetah. dan Teknol. Vol 1, vol. 1, no. April, pp. 119-124, 2018. 